\title{
Analisis dan Implementasi Sistem Monitoring Koneksi Internet Menggunakan The Dude Di STIKOM Al Khairiyah
}

\author{
Sutarti ${ }^{1)}$, Alif Alfiyansyah ${ }^{2)}$ \\ Program Studi Sistem Komputer, Fakultas Teknologi Informasi, Universitas Serang Raya \\ Jl. Raya Serang - Cilegon KM 5 Drangong Kota Serang, Banten \\ Isutarti86@gmail.com \\ ${ }^{2}$ alief.alfiyansah@gmail.com
}

\begin{abstract}
Abstrak - Monitoring jaringan merupakan kegiatan untuk mengelola suatu sistem jaringan di server atau area tertentu. Sistem monitoring ini dipergunakan untuk mempermudah teknisi dalam melakukan pemantauan secara rutin kondisi jaringan di server. Selain untuk pemantauan koneksi internet bisa juga untuk memantau bandwidth user yang sedang dipakai. Monitoring jaringan yang dilakukan menggunakan software the Dude dengan sistem operasi Mikrotik. Masalah yang terjadi adalah ketika melakukan sinkronisasi antara server the Dude sebagai pengirim dan gmail sebagai penerima di script the Dude sehingga sering terjadi error. Hasil yang diperoleh setelah diimplementasikan adalah staf lebih cepat dalam mendeteksi trouble pada jaringan dan mempermudah dalam penanganannya. The Dude juga memungkinkan untuk monitoring services yang berjalan pada tiap network, dan memberikan peringatan pada setiap perubahan statusnya.
\end{abstract}

Kata Kunci : Analisis, monitoring, koneksi internet, the Dude, server, bandwidth

\section{PENDAHULUAN}

Sistem monitoring telah banyak digunakan di bidang teknologi informasi yang bertujuan untuk mempermudah proses memperoleh informasi dengan cepat, tepat dan mudah. STIKOM Al Khairiyah pada saat ini masih memanfaatkan sistem manual dan menggunakan informasi seadanya dari server, sehingga pengawasan kecepatan traffic dan client jaringan untuk memantau penggunaan bandwidth seluruh traffic yang berjalan tidak bisa dikontrol ataupun direkam sendiri di server karena tidak ada monitoring. Bahkan jika terjadi troubleshooting jaringan, informasi yang diperoleh kurang optimal sehingga tidak bisa diperbaiki dengan cepat.

Berdasarkan keadaan tersebut maka dibutuhkan sistem monitoring menggunakan the Dude yang berfungsi untuk mendeteksi terjadinya troubleshooting jaringan. Informasi dari server bisa diketahui melalui sms, via gmail pada handphone sehingga bisa diperbaiki dengan cepat. The Dude merupakan sistem monitoring dari mikrotik yang dapat menjadi media untuk mengatur jaringan komputer. The Dude akan otomatis membaca dengan cepat semua alat atau komputer yang terhubung dalam satu jaringan lokal, menggambar rancangan peta dari jaringan lokal, mengamati layanan dari perangkat atau komputer dan memberitahu jika ada masalah layanan dari alat atau komputer dalam jaringan lokal LAN.

The Dude dapat melakukan scanning otomatis pada semua perangkat yang terhubung pada subnet jaringan tertentu. Hasil scanning-nya berupa gambar peta konfigurasi jaringan yang muncul secara otomatis. Peta konfigurasi jaringan ini akan menggambarkan kondisi jaringan apakah sedang up/down. Selain itu the Dude juga dapat menampilkan transfer rate antar perangkat di jaringan, jadi dapat memantau traffic yang berjalan di jaringan secara realtime dengan mudah. Yang lebih istimewa lagi, the Dude bisa digunakan pada perangkat selain Mikrotik. The Dude dapat mengidentifikasi secara otomatis jenis dari perangkat yang ada di jaringan dengan men-scan service yang digunakan oleh perangkat tertentu.

\section{METODOLOGI PENELITIAN}

Metode pengumpulan data yang digunakan dalam penelitian ini adalah:

a. Metode Wawancara. Wawancara dengan pihak-pihak yang berkaitan dengan penelitian. Teknik wawancara dilakukan dengan wawancara berstruktur. Dalam wawancara tersebut peneliti telah menyiapkan daftar pertanyaan yang berkaitan dengan prototipe. Pertanyaanpertanyaan untuk mendapatkan data yang terkait dengan sistem yang sedang berjalan saat ini.

b. Metode Observasi. Observasi atau pengamatan langsung terhadap profil organisasi dan obyek penelitian. Teknik observasi dilakukan dengan observasi berstruktur dengan menyiapkan daftar kebutuhan data dan sumber data. Proses observasi dilakukan untuk mempelajari, tujuan dan struktur organisasi, proses bisnis dan kebijakan sistem informasi yang telah ada di Stikom Al Khairiyah.

c. Metode Studi Pustaka. Metode pengumpulan data yang diperoleh dengan mempelajari, meneliti, dan membaca buku, jurnal, skripsi, tesis yang berhubungan dengan pengembangan sistem. 
Tabel 1. Analisis Perangkat Keras

\begin{tabular}{|l|l|}
\hline Perangkat Keras & Keterangan \\
\hline Processor & Dual Core \\
\hline Memory & Ram DDR II 2 GB \\
\hline Harddisk & 150 GB \\
\hline \multicolumn{2}{|c|}{ (Sumber : Dokumen Pribadi) }
\end{tabular}

Arsitektur Jaringan

\section{HASIL DAN PEMBAHASAN}

Arsitektur jaringan penyimpana data pusat yang menggunakan komputer windows pada STIKOM Al Khairiyah yang terhubung pada router mikrotik lingkup kantor yang terdapat di ruang server.

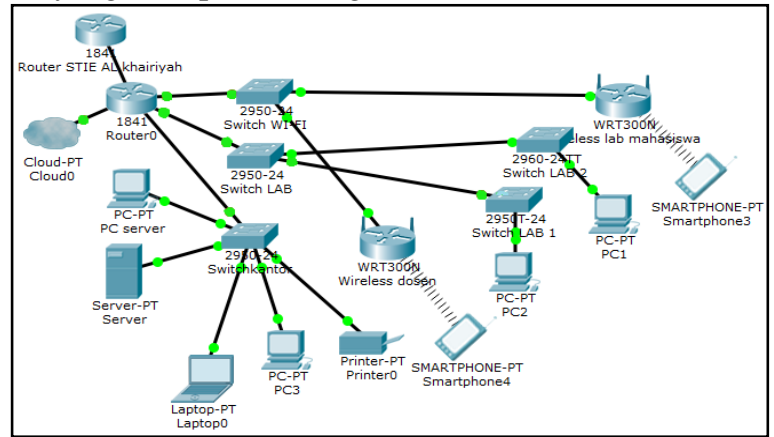

(Sumber: Dokumen pribadi)

Gambar 1. Arsitektur Jaringan Server STIKOM Al Khairiyah

Skema Jaringan

Skema jaringan penyimpanan data pusat menggunakan komputer yang sudah terinstalasi windows 7 yang ada di STIKOM Al Khairiyah sebagai tempat penyimpanan data pusat menggunakan topologi star, karena printer dan access point terhubung langsung pada switch kantor yang sudah terkoneksi pada router mikrotik.

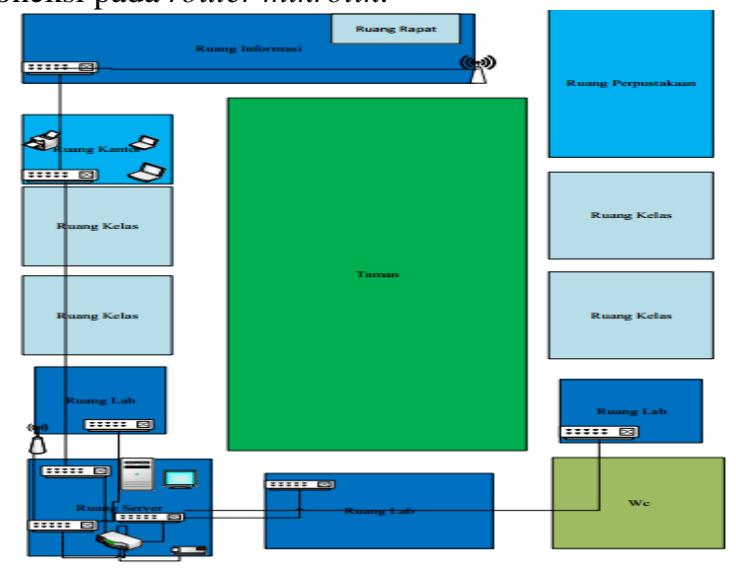

(Sumber : dokumen pribadi)

Gambar 2. Arsitektur Jaringan STIKOM Al Khairiyah

Sistem Monitoring Jaringan

Pada saat ini monitoring yang digunakan di STIKOM Al Khairiyah masih menggunakan monitoring manual. Oleh karena itu penelitian ini akan melakukan instalasi sistem monitoring jaringan server untuk mempermudah dalam mengetahui informasi bila terjadi troubleshooting.

Spesifikasi Hardware dan Software

Spesifikasi hardware dan software pada monitoring server masih sangat standar dan masih menggunakan sistem operasi Windows.
Tabel 2. Analisis Perangkat Lunak

\begin{tabular}{|l|l|}
\hline \multicolumn{1}{|c|}{ Perangkat Lunak } & Keterangan \\
\hline Sistem Operasi & Windows 7 Ultimate \\
\hline Winbox & Remote Mikrotik \\
\hline Time viewer & Remote Komputer \\
\hline The dude & Software monitoring jaringan \\
\hline
\end{tabular}

Permasalahan Sistem Jaringan

Permasalahan pada jaringan server yang digunakan sebagai informasi pusat sering tidak stabil jika banyak pengguna. Dan masih menggunakan sistem informasi dari setiap user sehingga bila terjadinya maintenance tidak bisa diperbaiki dengan cepat dan kurangnya informasi.

Alternatif Pemecahan Masalah

Dengan adanya monitoring server ini menggunakan sistem operasi windows 7 maka untuk memonitoring mudah sekali untuk mengawasi keseluruhan jaringan di server jika ada maintenance pada jaringan tersebut bisa mengetahui dalam sistem monitoring the dude sehingga bisa mengetahui informasi melalui notifikasi handpohe via gmail.

Skema Jaringan

Skema jaringan server yang ada di STIKOM al Khairiyah menggunakan topologi star yang menggunakan satu router, switch, POE TP-LINK, PC di ruang server, lab dan kantor. Di antaranya penjelasan alur jaringan dari swicth tersebut sebagai berikut:

1. Router server perangkat jaringan menggunakan IP Address dan penerus paket data antara dua segmen jaringan atau lebih. untuk meneruskan data dari satu jaringan ke jaringan lain.

2. Switch server menghubungkan jaringan komputer pada setiap ruangan lab, kantor, ruangan akademik letak switch ini terletak pada ruangan server.

3. Switch lab satu dan dua yang menghubungkan jaringan komputer lokal pada ruang lab letak switch ini berada di depan lab STIKOM.

4. Switch kantor menghubungkan khusus ruangan akademik, yang kemudian terpecah untuk jaringan kantor itu sendiri dan hotspot atau wifi yang bisa digunakan untuk mahasiswa. 


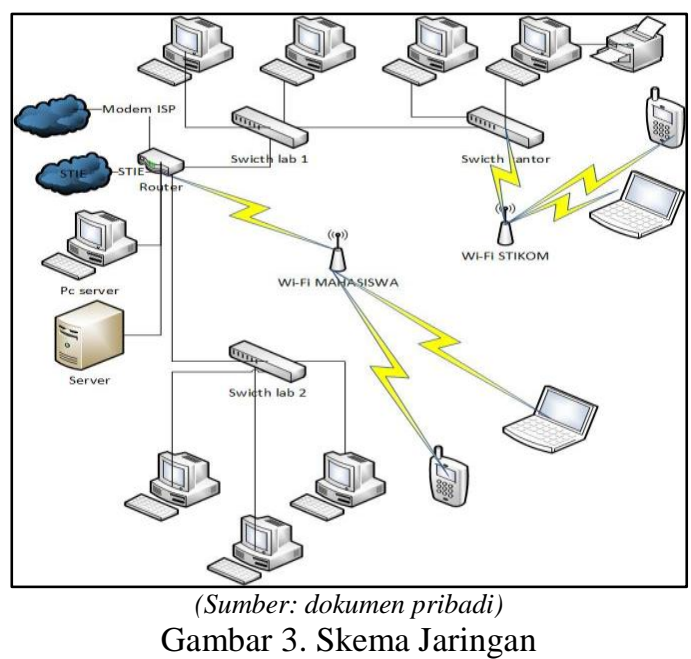

Rancang Aplikasi

\section{Hardware}

Kebutuhan hardware yang diperlukan adalah komputer dengan spesifikasi seperti pada tabel 3 .

Tabel 3. Spesifikasi Komputer

\begin{tabular}{|l|l|}
\hline \multicolumn{1}{|c|}{ Hardware } & \multicolumn{1}{c|}{ Keterangan } \\
\hline Processor & Dual core \\
\hline Memory & RAM DDR II 2 GB \\
\hline Harddisk & 150 GB \\
\hline Winbox & Remote mikrotik \\
\hline Time viewer & Remote komputer \\
\hline The dude & Software monitoring jaringan \\
\hline Swicth & Pengatur pembagi sinyal data \\
\hline Router & Penghubung antar dua jaringan \\
\hline Access point & Pemancar sinyal WI-FI \\
\hline \multicolumn{2}{|c|}{ (Sumber : dokumen pribadi) }
\end{tabular}

\section{Software}

Berikut kebutuhan software yang diperlukan:

1. OS Windows 7 yang digunakan untuk instalasi the Dude.

2. The Dude merupakan jaringan monitoring dan secara online mampu memetakan jaringan keseluruhan perangkat yang terhubung dalam jaringan.

\section{Instalasi sistem}

Berikut ini tahapan instalasi monitoring the Dude menggunakan Mikrotik melalui Winbox. Untuk mengkonfigurasi mikrotik juga bisa melakukan remote setiap client pada server mikrotik Router OS. Untuk melakukan konfigurasi mikrotik harus membuka Winbox akan muncul seperti tampilan gambar 4 .

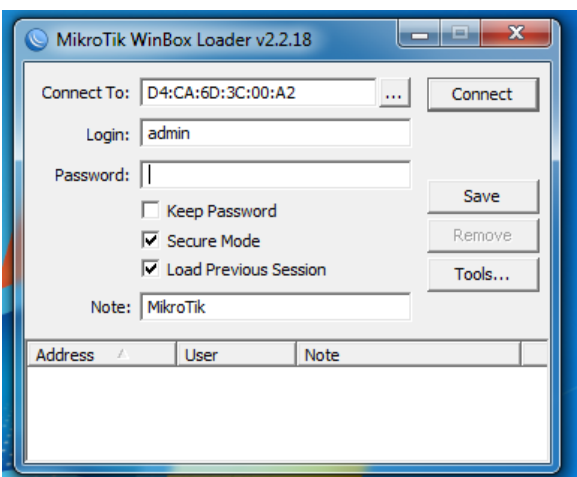

(Sumber: dokumen pribadi)

Gambar 4. Tampilan Winbox

Jalankan aplikasi winbox yang telah di-download, login dengan make address yang telah ada dengan cara mengklik tabel connect. Setelah login akan terdapat banyak menu tab sebelah kiri yang yang telah disediakan oleh aplikasi winbox untuk untuk mengkonfigurasi sebuah mikrotik.

Langkah awal mengklik tab interface maka setiap ether mikrotik akan terbaca dan tinggal mengklik dua kali di setiap interface yang akan diubah nama setiap ether sehingga muncul gambar 5 .

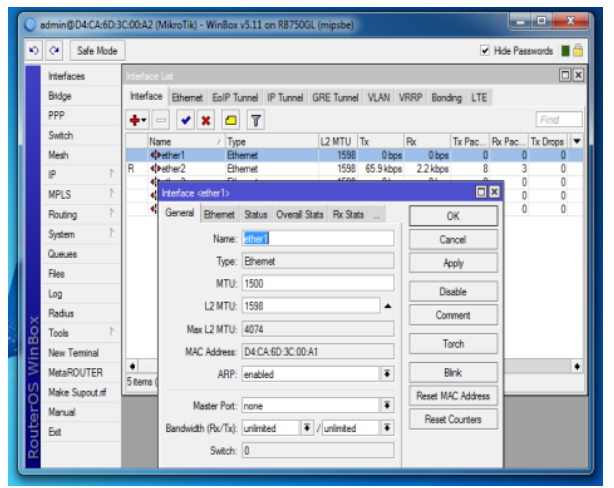

(Sumber: dokumen pribadi)

Gambar 5. Pengubahan Nama Ether

Setting IP Address

Untuk mengkonfigurasi IP address bisa mengklik tabel IP dan memilih tabel address (+) sehingga muncul tabel baru seperti gambar 6 .

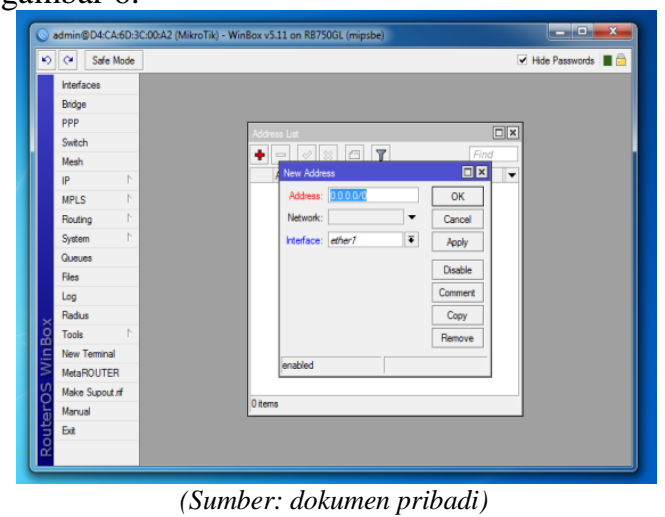

Gambar 6. Penambahan IP Address 


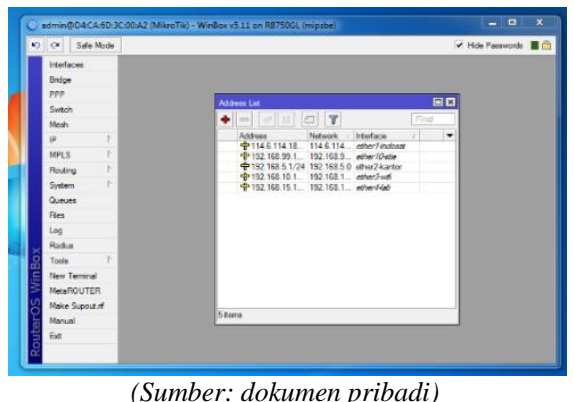

Gambar 7. Daftar IP Keseluruhan Ether

Setelah Konfigurasi router yang telah di-setting telah memiliki IP address di setiap IP address. Bisa saja menggunakan tombol navigasi di atas untuk menghapus atau menambah IP address dan bisa juga meng-enable dan disable dengan mengklik IP address dan klik tombol $(\mathrm{x})$ atau $(\sqrt{ })$. Untuk selanjutnya setting IP DNS yang telah mendapatkan IP ISP internet klik table IP lalu pilih DNS memasukkan DNS yang ada pada server mencentang allow remote request.

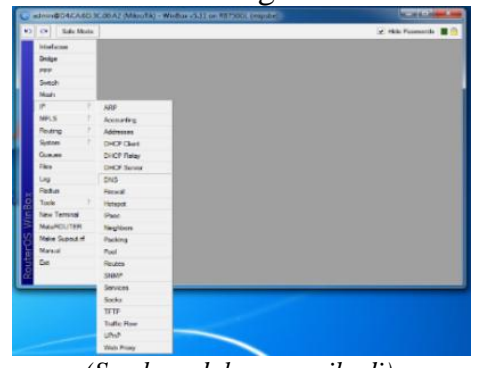

(Sumber: dokumen pribadi)

Gambar 8. Konfigurasi DNS

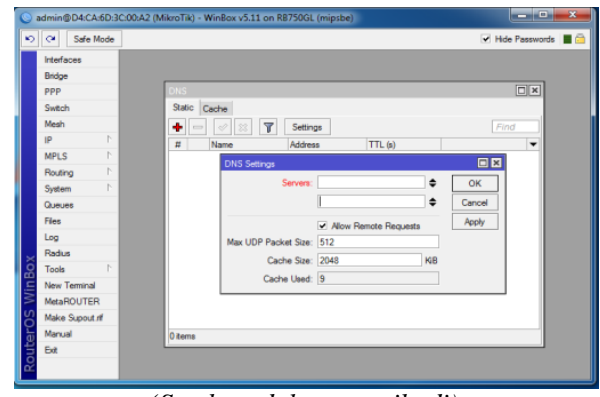

(Sumber: dokumen pribadi)

Gambar 9. Tampilan Menu Setting DNS

Setelah konfigurasi DNS yang telah dimasukkan di setiap ether lakukan konfigurasi gateway dengan mengklik tabel IP pilih tabel routes pada route list buat baru add (+) lalu pada gateway value isi alamat gateway pada modem.

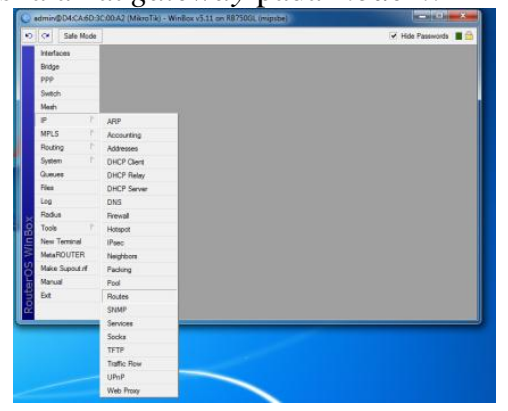

(Sumber: dokumen pribadi)

Gambar 10. Konfigurasi IP Gateway

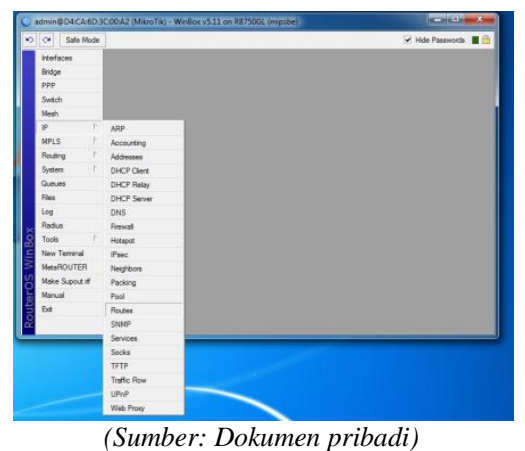

Gambar 11. Setting IP Gateway

Untuk memberikan akses internet kepada komputer lain konfigurasi yang harus dilakukan dengan cara memilih tabel IP, Firewall pilih tab NAT klik (+) yang terpenting adalah pilih out interface ether satu untuk terhubung ke internet. setelah konfigurasi general pilih menu tabel Action memilih menu masquered dan klik ok.

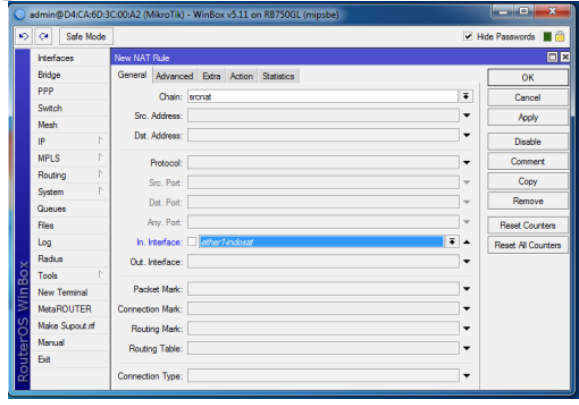

(Sumber: Dokumen pribadi)

Gambar 12. Tampilan Konfigurasi Firewall

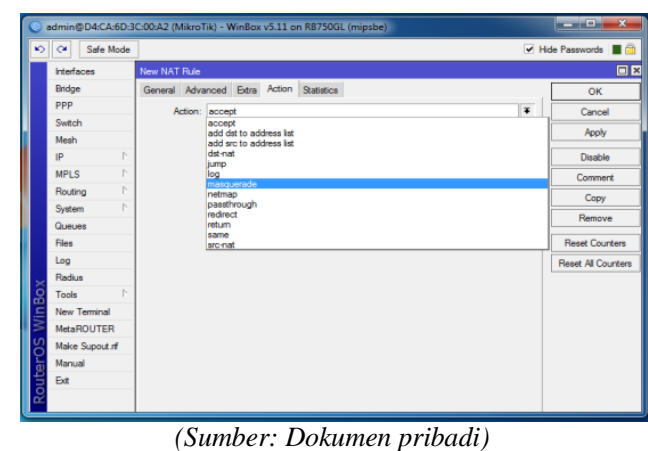

Gambar 13. Konfigurasi Firewall

Monitoring dan Konfigurasi The Dude

Software the Dude, dapat diunduh pada website mikrotik seperti gambar 14. 


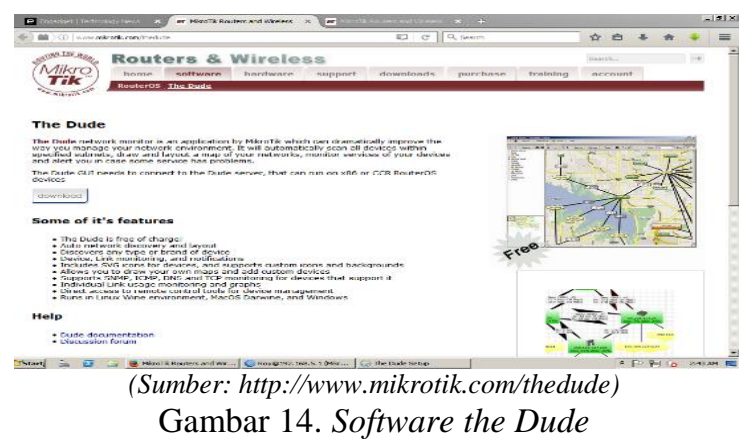

Setelah file yang telah diunduh yang berekstensi *.exe klik Run as maka akan muncul pilihan dan pilih I Agree sehingga tunggu dengan klik next, klik install. Tunggu sehingga selesai dan klik close seperti gambar berikut ini.

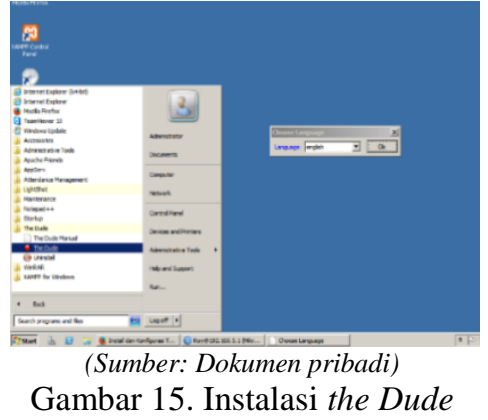

Setelah masuk program the Dude setting pada device discovery. Pada tab General from discovery mode pilih realiable (scan each service) From discovery yang akan mencari sebuah komputer pada jaringan yang terhubung dalam satu subnet.

Untuk melihat pengaturan yang akan disesuaikan ada pada tab device type akan di-scan di antaranya bridge, FTP server, mikrotik device, mail dan lain-lain dalam discovery network atau scanning network setelah terhubung dengan memasukkan subnet IP tunnggu hingga prosess scanning seluruh IP yang sudah terkoneksi muncul.

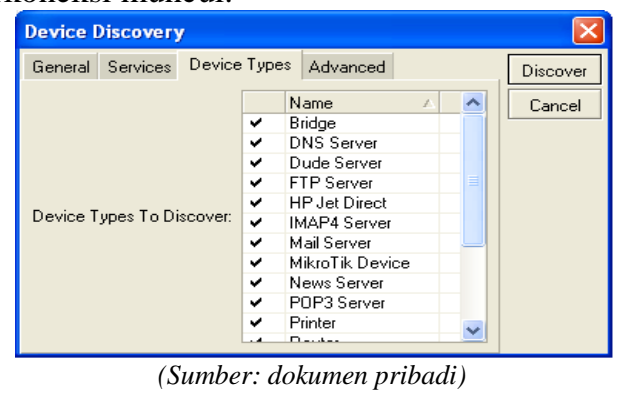

Gambar 16. Setting the Dude

Untuk melihat setting monitoring lainnya jika sudah klik discovery maka program akan melakukan scanning dengan otomatis membaca semua komputer yang telah terhubung dalam jaringan satu jaringan lokal untuk pengujian monitoring jaringan the dude discovery masukan IP server berserta yang digunakan untuk me-remote the Dude tunggu sehingga proses scanning selesai seperti gambar 17 (network yang ter-scan adalah network dalam posisi online.)

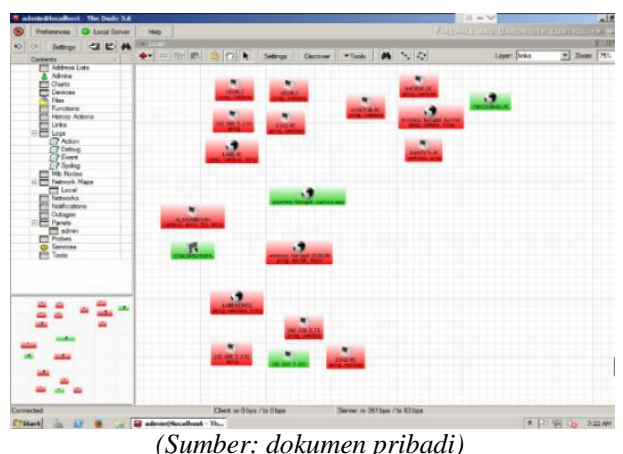

Gambar 17. Discovery the Dude

Secara manual dapat mengatur layout serta tampilan dengan keinginan bisa memilih beberapa opsi di antaranya adalah device, network, submap, static, dan link bisa dilihat dengan mengklik tombol add [+] pada lingkaran gambar 18 .

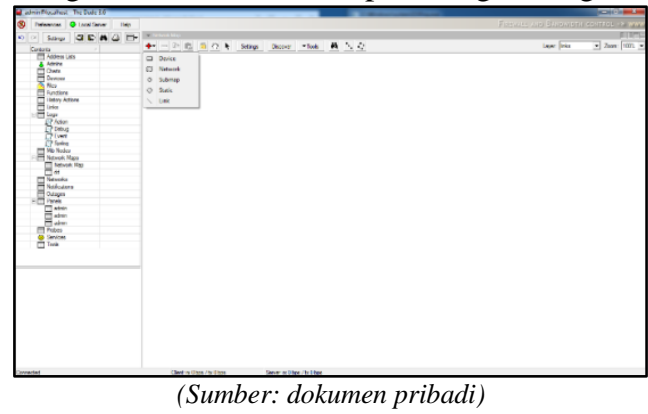

Gambar 18. Konfigurasi Device secara Manual

Konfigurasi pemberitahuan E-mail di monitoring system the Dude dapat bekerja hanya dengan server. Menggunakan layanan gmail untuk mengirim pemberitahuan otorisasi SMTP dengan cara men-download mailsend.exe dan membuat script-nya.

Untuk mengkonfigurasi notifikasi gmail yang telah didownload mailsend.exe dapat disimpan di disk $\mathrm{C}$, file program, file (86) Dude, membuat file mailsend dan menyimpan mailsend.exe dan membuat script mailsend dengan memberi nama mailsend.cmd type file all files seperti gambar 19.

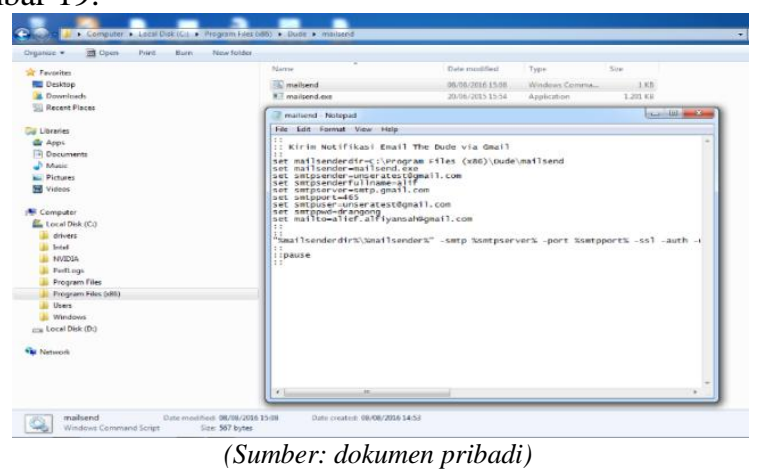

Gambar 19. Setting File Mailsend the Dude

Pengujian Jaringan Awal

Hasil pengecekan IP address yang telah terkoneksi pada jaringan mikrotik dan internet terlihat pada kolom yang berwarna merah seperti terlihat pada gambar 20 . 


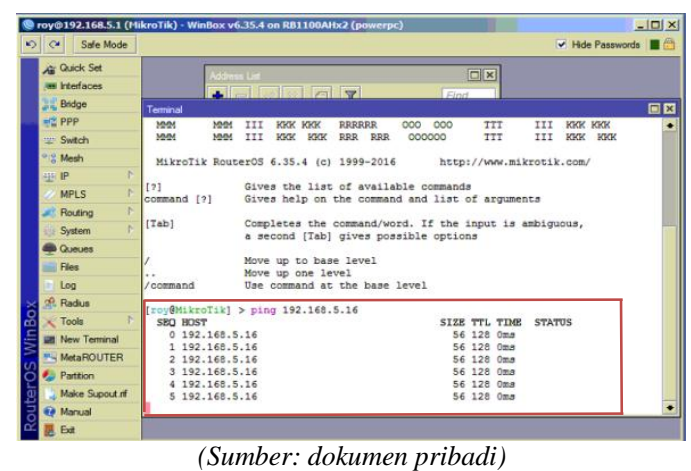

Gambar 20. Tes Koneksi Antara Client dan Jaringan

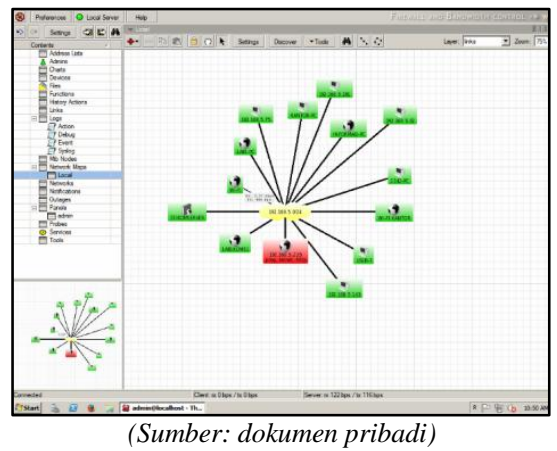

Gambar 21. Topologi Jaringan the Dude di Server

Dari gambar 21 dapat diketahui kondisi masing-masing perangkat, dapat juga diketahui transfer rate antar perangkat (router)

Pengujian Jaringan Akhir

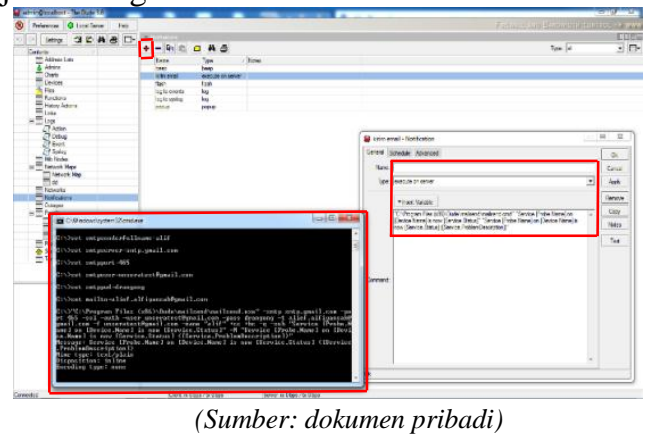

Gambar 22. Setting Notifikasi Server

Setting notifikasi gmail untuk akses dan penambahan bisa dilihat dengan mengklik tabel notifikasi, tanda (+) untuk menambahkan notifikasi memilih excute on server dan mengisi lokasi file yang telah disimpan di folder $\mathrm{C}$ bila sudah terisi bisa melakukan tes dan akan menampilkan CMD.

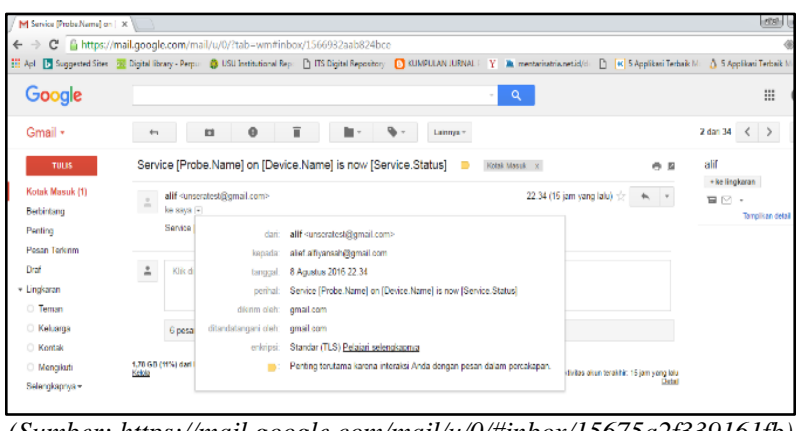

(Sumber: https://mail.google.com/mail/u/0/\#inbox/15675a2f339161fb)

Gambar 23. Tampilan Notifikasi pada Gmail

Sistem notifikasi server gmail di the Dude menggunakan SMTP yang sudah di-setting sudah tervalidasi pada gmail seperti gambar 23 .

Kesimpulan

\section{KESIMPULAN}

Setelah analisis dan implementasi sistem monitoring jaringan menggunakan mikrotik OS dan the Dude maka beberapa kesimpulan mengenai monitoring jaringan server di STIKOM al Khairiyah sebagai berikut:

1. Penggunaan mikrotik $O S$ dan the Dude sebagai monitoring jaringan di STIKOM al Khairiyah berhasil diimplementasikan sehingga lebih cepat mendeteksi trouble jaringan dan mempermudah dalam penanganannya.

2. The dude monitoring service berjalan pada tiap network dan memberi peringatan pada setiap perubahan koneksi.

Saran

Saran untuk pengembangan monitoring jaringan menggunakan mikrotik os dan the Dude adalah perlu adanya perawatan koneksi server untuk mengetahui secara umum tentang jaringan koneksi internet yang digunakan atau agar tidak terjadi gangguan pada jaringan atau looping sehingga mengganggu aktifitas.

\section{REFERENSI}

[1] Yudha, A.A. (2016). Pengertian Topologi Jaringan Komputer \& Macam-macam Jenisnya. [Online]. Tersedia: http://teknodaily.com/pengertian-topologi-jaringankomputer-macam-macam-jenisnya/. [20 Juli 2016].

[2] Yudha, A.A. (2016). Macam-macam Perangkat Keras Jaringan Komputer Beserta Fungsinya. [Online]. Tersedia: http://teknodaily.com/macam-macam-perangkatkeras-jaringan-komputer-beserta-fungsinya/. [20 Juni 2016].

[3] Achmad, A. dkk (2013). "Rancang Bangun Network Mapping Sistem Monitoring Jaringan”. Jurnal Teknik POMITS Vol. 1.

[4] Delhendro. (2015). Pengertian dan Fungsi Winbox. [Online]. Tersedia : http://www.delhendro.com/2012/ 11/pengertian-dan-fungsi-winbox.html. [27 Juni 2016].

[5] Fajar. (2016). Pengertian Access Point Giant Computer. [Online]. Tersedia: http://giant-computer.com/pengertian- 
dan-fungsi-switch-router-hub-access-point-rj-45-modemkabel-utp-nicrepeater-bridge-satelit-kabel-coaxial-danusb-wifi/. [25 Juni 2016].

[6] Kusuma, U. (2014). Tentang Penjelasan Nagios. [Online]. Tersedia : $\quad$ http://www.ulungkusuma.web. $\mathrm{id} / \mathrm{html} /$ index.php?id=artikel\&kode=93 . [26 Juni 2016].

[7] Mikrotik Indonesia [2016]. Penjelasan mikrotik. [Online]. Tersedia: http://mikrotik.co.id/artikel-lihat.php?id=81. [25 Juli 2016].

[8] Novianti, W. (2016). Pengertian Sistem Operasi Windows. [Online]. Tersedia: https://www.academia. edu/6808054/pengertian-sistem-Operasi-Windows-adalahsistem. [25 Juni 2016].

[9] Robertus, R.S. dkk (2015). "Perancangan Sistem Monitoring pada Jaringan Load Balancing Menggunakan Munin Monitoring”. Jurnal Jarkom Vol. 3 No. 1.
[10] Setiawan, A. (2012). Penjelasan Kelas-kelas IP Address. [Online].

Tersedia: http://www.transiskom.com/2012/10/kelas-kelas-ipaddress.html. [20 Juni 2016].

[11] Universitas Serang Raya (UNSERA). (2015). Pedoman Penulisan Karya Ilmiah. UNSERA. Serang

[12] Wijono, D. (2014). "Zabbix Network Monitoring sebagai Perangkat Monitoring Jaringan di SKPD Kota Malang". Jurnal ELTEK, Vol 12 No. 01 ISSN 16934024.

[13] Wardani, F. (2012). Monitoring Jaringan Menggunakan PRTG. [Online]. Tersedia: https://www.scribd.com/doc/100587663/Laporan-PRTG. [24 Juni 2016]. 